\title{
Study of Application of Composite Coating of Guar Gum-Garlic Oil on Grapes
}

\author{
Jagruti Jankar $^{1 *}$, Vasant Pawar ${ }^{1}$ and Ajay KumarSharma ${ }^{2}$ \\ ${ }^{1}$ MIT College of Food technology, MIT ADT University, Pune, India \\ ${ }^{2}$ ICAR-National Research Centre of Grapes, Pune, India
}

Keywords

Thompson

Seedless, Shelf life,

Storage, Quality,

Microbial status,

Antioxidants

Article Info

Accepted:

22 December 2019

Available Online:

20 January 2020

\section{A B S T R A C T}

Prevailing high temperature during harvesting to consumption of grapes in India results in accelerated water loss, faster respiration, physiological weight loss, rachis browning, berry shattering, poor shelf life and finally leads to significant post-harvest losses. Fruit surface is protected by the application of coating to maintain its freshness and shelf life for longer duration. Present experiment was designed to determine the effectiveness of guar gum (GG)/Garlic Oil (GO) composite coatings for maintaining the quality of Thompson Seedless grapes while stored at $10^{\circ} \mathrm{C}$ and $60-65$ per cent relative humidity. Coating emulsions were formulated using guar gum ( 0.5 per cent $)$ with different $\mathrm{GO}$ concentrations viz., $0.125,0.5$ and 1 per cent as $\mathrm{T} 1, \mathrm{~T} 2, \mathrm{~T} 3$, respectively and uncoated grapes were used as a control (T4). The recorded data showed that coated berries were registered with delayed changes in total soluble solids and titratable acidity in comparison to control. Physiological loss in weight in coated treatments were effectively lowered. Antioxidant activities and total phenols were increased in treated berries during the storage. Microbial load and total plate counts were decreased in coated berries. Among four treatments, T2 and T3 showed better results than other treatments. Results of present study indicated that treatment T2 was effective in maintaining quality of Thompson Seedless grapes when stored at $10^{\circ}$ and $60-65$ per cent $\mathrm{RH}$.

\section{Introduction}

Grape cultivation is one of the most remunerative farming enterprises in India. The majority of commercial grape production in India is located in the tropical regions of Maharashtra, Karnataka, Tamil Nadu and Andhra Pradesh. In addition, around 95 per cent of the total grapes are produced from
Maharashtra and Karnataka. Under tropical conditions of India, grapes face higher temperature from veraison to harvesting and up to retailing. Prevailing higher temperature and poor handling and supply management lead to wide postharvest losses (Sharma et al., 2018).The losses of quality are based on weight loss, color changes, accelerated softening, rachis browning, and high 
incidence of berry decay (Crisosto et al.,2002), which lead to a reduction of shelf life. Presenting use of bio-based materials as a way of extending the shelf life of extremely perishable fruits and vegetables is encouraging.

The coatings create a semi-permeable shield for water vapour and gas transfer, contributing to a decrease in weight loss, respiration rate and a lag in senescence (Tharanathan, 2003).

Edible coatings comprise of polysaccharides, carbohydrates, lipids or a combination of these. Their existence and concentration decide the barrier properties of the substance in relation to water vapour, oxygen, carbon dioxide and lipid transport in food systems (Guilbert et al., 1996).

Guar gum, a galactomannan rich, water soluble polysaccharide obtained from the Indian legume cluster Cyamopsis tetragonoloba (L.) and have been used as coating materials by many researchers. Essential oils (EOs) obtained from natural crops and spices are established for their antimicrobial annd antioxidant characteristics and do not leave any residual impact due to their volatile nature (Viuda et al.,2011).

Garlic oil (GO) is an essential oil and its subsidiary products suchas dialylsulphide, dialyldisulphide, dialyltrisulphide and ajoene may inhibit a plethora of microorganisms including bacteria, molds, fungi, and parasites. Limited research data on GO integrated in composite coatings or films are available (Ponce et al., 2008; Corzo et al.,2008; Pranoto et al., 2005) and no study is to be conducted on guar gum (GG) integrated in $\mathrm{GO}$ composite coatings on grapes.

In the present endeavor, GO has been chosen as a hydrophobic and antimicrobial agent to enhance the appropriate characteristics of guar gum for fruit coating. The objective of the present study was to elucidate the ability of guar gum integrated with GO composite coatings to maintain grapes quality at $10^{\circ} \mathrm{C}$ and $64 \% \mathrm{RH}$.

\section{Materials and Methods}

Present work was carried out at ICARNational Research Centre for Grapes, Pune during the fruiting season of 2018-19.Pune is situated in Midwest Maharashtra State (India) at an altitude of $559 \mathrm{~m}$ above mean sea level. It lies on $18.32^{\circ} \mathrm{N}$ latitude and $73.51^{\circ} \mathrm{E}$ longitude. Thompson Seedless variety grapes were utilized in the study. Fresh healthy grapes bunches were obtained from the farm of ICAR-NRCG, Pune.

\section{Coating of grapes}

The material for coatings were prepared by adding different concentrations of garlic essential oil to guar gum. The garlic oil was procured from market and added in $100 \mathrm{ml}$ water as $0.125(\mathrm{~T} 1), 0.5(\mathrm{~T} 2)$ and $1 \mathrm{ml}$ (T3)with0.25\%Guar gum solution. Glycerol as plasticizer was added at the concentration of $0.4 \%$ to each solution and was stirred for $30 \mathrm{~min}$.

Bunches were dipped in different treatments solutions for $2 \mathrm{~min}$, dried in room temperature, kept in air perforated plastic containers and stored at $10^{\circ}$ and $64 \%$ relative humidity while in control (T4) no treatment was applied. Data on physicochemical parameters such as physiological weight loss, TSS, titratable acidity, total phenol content, per cent inhibition, and microbial load were recorded on an interval of 7 days. In each treatment one grape bunch was selected and replicated five times. 


\section{Physiological loss in weight (PLW)}

The physiological loss in weight was determined by gravimetric analysis, using Equation (1)(Restrepo et al.,2010).

$$
\% \mathrm{PLW}=\frac{\mathrm{Pi}-\mathrm{Pf}}{\mathrm{Pi}} \mathrm{X} 100
$$

Whereas,

$\%$ PLW is the percentage physiological weight loss and $\mathrm{Pi}$ and $\mathrm{Pf}$ are the initial and final weight of the sample $(\mathrm{g})$, respectively.

\section{Total soluble solids and titratable acidity}

Total soluble solid (TSS) contents were determined with a digital refractometer for the juice of 10-20 berries for each treatment. Titratable acidity (TA) was determined by titration of $25 \mathrm{ml}$ of filtered juice with the addition of $0.1 \mathrm{~N}$ sodium hydroxide of $\mathrm{pH} 8.2$ to an end point.

\section{Antioxidant Activity}

To evaluate the evolution of the antioxidant activity of the grape treatments during storage, the method of 2,2- diphenyl-1picrylhydrazyl (DPPH during 30min of reaction) was adopted wherein the radicals were trapped after treatment with coatings applied to grapes. (Martinez et al.,2018). It was expressed as \% inhibition of DPPH.

\section{Total phenolic content}

Total phenolic content was determined by using the Folin- Ciocalteu method (Singleton and Rossi, 1965), using gallic acid as the standard. The concentration of the total phenolics was expressed as gallic acid equivalent (GAE $\mathrm{mg} / \mathrm{g}$ ) of the sample.

\section{Microbial Load}

Total plate count along with yeast and mould count was done according to protocols of FAO, 1992. The total count was calculated from the mean count of five replications of Petri dishes.For yeast and mould, spread plate method was used. Formula:

Colony Forming Unit (CFU/ml)

(number of colonies forming unit grow* $n$ )*

$=\frac{\text { *dilution factor* conversion factor }}{\text { volume of diluted broth with fungi plate }}$

\section{Statistical Analysis}

The collected data were analyzed in Complete Randomized Design and SAS software was used for data analysis.

\section{Total Soluble Solids (TSS)}

Table.1 Effect of different garlic treatments on TSS $\left({ }^{\circ} \mathrm{B}\right)$ of grapes

\begin{tabular}{|c|c|c|c|c|c|}
\hline Treatments & \multicolumn{5}{|c|}{ Storage days } \\
\hline & $\mathbf{0}$ & $\mathbf{7}$ & $\mathbf{1 4}$ & $\mathbf{2 1}$ & $\mathbf{2 8}$ \\
\hline T1 & $19.34^{\mathrm{b}}$ & $20.16^{\mathrm{b}}$ & $20.78^{\mathrm{bc}}$ & $21.74^{\mathrm{b}}$ & $22.68^{\mathrm{a}}$ \\
\hline T2 & $19.68^{\mathrm{b}}$ & $20.20^{\mathrm{b}}$ & $20.68^{\mathrm{c}}$ & $21.38 \mathrm{~b}$ & $21.78^{\mathrm{b}}$ \\
\hline T3 & $20.28^{\mathrm{a}}$ & $21.22^{\mathrm{a}}$ & $21.74^{\mathrm{a}}$ & $22.46 \mathrm{a}$ & $23.04^{\mathrm{a}}$ \\
\hline T4 & $19.36^{\mathrm{b}}$ & $20.42^{\mathrm{b}}$ & $21.26^{\mathrm{ab}}$ & $21.76^{\mathrm{b}}$ & $22.88^{\mathrm{a}}$ \\
\hline LSD at 5\% & 0.35 & 0.41 & 0.50 & 0.50 & 0.43 \\
\hline
\end{tabular}




\section{Titratable Acidity}

Table.2 Effect of different garlic treatments on Acidity (\%) of grapes

\begin{tabular}{|c|c|c|c|c|c|}
\hline Treatments & \multicolumn{5}{|c|}{ Storage days } \\
\hline & $\mathbf{0}$ & $\mathbf{7}$ & $\mathbf{1 4}$ & $\mathbf{2 1}$ & $\mathbf{2 8}$ \\
\hline T1 & $0.40^{\mathrm{c}}$ & $0.36^{\mathrm{c}}$ & $0.45^{\mathrm{a}}$ & $0.44^{\mathrm{a}}$ & $0.35^{\mathrm{a}}$ \\
\hline T2 & $0.42^{\mathrm{a}}$ & $0.49^{\mathrm{a}}$ & $0.31^{\mathrm{c}}$ & $0.26^{\mathrm{c}}$ & $0.40^{\mathrm{c}}$ \\
\hline T3 & $0.42^{\mathrm{b}}$ & $0.41^{\mathrm{b}}$ & $0.37^{\mathrm{b}}$ & $0.35^{\mathrm{b}}$ & $0.39^{\mathrm{b}}$ \\
\hline T4 & $0.42^{\mathrm{bc}}$ & $0.36^{\mathrm{c}}$ & $0.32^{\mathrm{c}}$ & $0.22^{\mathrm{d}}$ & $0.27^{\mathrm{d}}$ \\
\hline LSD at 5\% & 0.020 & 0.019 & 0.021 & 0.017 & 0.014 \\
\hline
\end{tabular}

Total phenols

Table.3 Effect of different garlic treatments on total phenols $(\mathrm{mg} / \mathrm{g})$ of grapes

\begin{tabular}{|c|c|c|c|c|c|}
\hline & \multicolumn{5}{|c|}{ Storage days } \\
\hline Treatments & $\mathbf{0}$ & $\mathbf{7}$ & $\mathbf{1 4}$ & $\mathbf{2 1}$ & $\mathbf{2 8}$ \\
\hline T1 & $1.06^{\mathrm{a}}$ & $1.10^{\mathrm{b}}$ & $1.12^{\mathrm{c}}$ & $1.17^{\mathrm{b}}$ & $1.27^{\mathrm{b}}$ \\
\hline T2 & $1.06^{\mathrm{a}}$ & $1.22^{\mathrm{a}}$ & $1.27^{\mathrm{b}}$ & $1.46^{\mathrm{a}}$ & $1.52^{\mathrm{a}}$ \\
\hline T3 & $1.02^{\mathrm{b}}$ & $1.23^{\mathrm{a}}$ & $1.12^{\mathrm{c}}$ & $1.43^{\mathrm{a}}$ & $1.54^{\mathrm{a}}$ \\
\hline T4 & $0.87^{\mathrm{c}}$ & $0.80^{\mathrm{d}}$ & $0.77^{\mathrm{c}}$ & $0.75^{\mathrm{c}}$ & $0.71^{\mathrm{c}}$ \\
\hline LSD at 5\% & 0.0412 & 0.0508 & 0.0611 & 0.0382 & 0.0384 \\
\hline
\end{tabular}

\section{Antioxidant Activity}

Table.4 Effect of different garlic treatments on antioxidant activity (\%) of grapes

\begin{tabular}{|c|c|c|c|c|c|}
\hline & \multicolumn{5}{|c|}{ Storage days } \\
\hline Treatments & $\mathbf{0}$ & $\mathbf{7}$ & $\mathbf{1 4}$ & $\mathbf{2 1}$ & $\mathbf{2 8}$ \\
\hline T1 & $61.14^{\mathrm{c}}$ & $62.13^{\mathrm{c}}$ & $62.46^{\mathrm{b}}$ & $62.71^{\mathrm{b}}$ & $62.79^{\mathrm{b}}$ \\
\hline $\mathbf{T 2}$ & $72.84^{\mathrm{a}}$ & $73.11^{\mathrm{a}}$ & $73.05 \mathrm{a}$ & $73.46^{\mathrm{a}}$ & $73.85^{\mathrm{a}}$ \\
\hline T3 & $72.03^{\mathrm{b}}$ & $72.21^{\mathrm{b}}$ & $72.29^{\mathrm{a}}$ & $72.71^{\mathrm{a}}$ & $73.11^{\mathrm{a}}$ \\
\hline T4 & $58.22^{\mathrm{d}}$ & $57.04^{\mathrm{d}}$ & $56.49^{\mathrm{c}}$ & $54.78^{\mathrm{c}}$ & $53.75^{\mathrm{c}}$ \\
\hline LSD at 5\% & 0.72 & 0.74 & 0.98 & 1.11 & 1.09 \\
\hline
\end{tabular}




\section{Physiological loss in weight (PLW)}

Table.5 Effect of different garlic treatments on physiological loss in weight (\%) of grapes

\begin{tabular}{|c|c|c|c|c|}
\hline \multirow{2}{*}{ Treatments } & \multicolumn{4}{|c|}{ Storage days } \\
\cline { 2 - 5 } & 7 & 14 & 21 & 28 \\
\hline T1 & $4.32^{\mathrm{b}}$ & $10.63^{\mathrm{b}}$ & $15.14^{\mathrm{b}}$ & $25.15^{\mathrm{b}}$ \\
\hline T2 & $3.42^{\mathrm{c}}$ & $8.43^{\mathrm{d}}$ & $12.65^{\mathrm{c}}$ & $23.18^{\mathrm{c}}$ \\
\hline T3 & $3.46^{\mathrm{c}}$ & $9.14^{\mathrm{c}}$ & $12.63^{\mathrm{c}}$ & $23.39^{\mathrm{c}}$ \\
\hline T4 & $5.74^{\mathrm{a}}$ & $11.42^{\mathrm{a}}$ & $16.51^{\mathrm{a}}$ & $26.04^{\mathrm{a}}$ \\
\hline LSD at 5\% & 0.20 & 0.09 & 0.41 & 0.87 \\
\hline
\end{tabular}

Microbial Load

Table.6 Microbial count in CFU/ml

\begin{tabular}{|c|c|c|c|}
\hline Treatments & Storage Days & Bacterial Count & Yeast and Mould \\
\hline \multirow{5}{*}{ T1 } & 0 & ND & ND \\
\hline & 7 & ND & ND \\
\hline & 14 & 5 & ND \\
\hline & 21 & 61 & 3 \\
\hline & 28 & $>300$ & 7 \\
\hline \multirow[t]{5}{*}{$\mathbf{T 2}$} & 0 & ND & ND \\
\hline & 7 & ND & ND \\
\hline & 14 & ND & ND \\
\hline & 21 & 10 & 2 \\
\hline & 28 & 14 & 4 \\
\hline \multirow[t]{5}{*}{ T3 } & 0 & ND & ND \\
\hline & 7 & ND & ND \\
\hline & 14 & 5 & ND \\
\hline & 21 & 12 & 4 \\
\hline & 28 & 13 & 6 \\
\hline \multirow[t]{5}{*}{ T4 } & 0 & ND & ND \\
\hline & 7 & ND & ND \\
\hline & 14 & 19 & 4 \\
\hline & 21 & 82 & 8 \\
\hline & 28 & $>300$ & 10 \\
\hline
\end{tabular}

Note -ND: Not Detected 
Results given in table 1 showed that among all the treated samples, grapes coated with T2 showed minimum increase in total soluble solid content by $2.1^{\circ} \mathrm{B}$. Conversely, T4 (Control) showed highest increase in total soluble solids i.e. by $3.52^{\circ} \mathrm{B}$ followed by $\mathrm{T} 1$ which is $3.34^{\circ} \mathrm{B}$. In this study, lower values of total soluble solids indicated delayed ripening of the fruits in T2. The results obtained for the change in TSS content agreed with the data reported by Asghari et al., (2011) wherein total soluble solids content was retained in coated grapes with aloe vera and salicylic acid during storage.

The lower total sugars were due to the decrease in respiration rate of the product because of coating layer. Increase in sugars during storage took place due to the degradation of polysaccharides into simple sugars as reported by Naik et al.,(1993) in tomatoes. Additionally, total soluble solids (TSS) were significantly increased in uncoated kinnows compared to coated ones, which might be due to the barrier provided by coating against respiration and evaporation and higher TSS in oranges has been related to an increased rate of respiration and evaporation from the fruit's surface (Thakur et al., 2002).

From the table 2, it can be depicted that by increasing storage duration, titratable acidity was decreased in all treatments. Significant difference was observed among all treatments. Grapes coated with T2 showed minimum decrease in TA by $0.02 \%$. Contrarily, T4 (control) showed highest decrease in TA by $0.15 \%$ followed by T1 by $0.05 \%$. . Among all treatments, T2 exhibited as slow decreasing trend in TA, while uncoated fruits showed a larger decreasing trend in TA during cold storage. Slower TA reductions indicated a slower ripening process that occurred with $\mathrm{T} 2$ treatment. These results are in agreement with Ullah et al., (2017).
They revealed that gum arabic coating with incorporated essential oil delayed the decrease in titratable acidity of bell pepper. The coating treatments showed an increasing trend in total phenol content with the storage period. Among all, T3 showed highest increase in TPC by $0.52 \mathrm{mg} / \mathrm{g}$ succeeding treatment T2which showed increase by $0.46 \mathrm{mg} / \mathrm{g}$. Reduction in phenol content was found in control which may be due to the oxidation by polyphenol oxidase (PPO) (Altunkaya and Gokmen, 2008) and due to the breakdown of cell structure as the fruit senesced (Gol et al.,2013).

The reason behind the increase in TPC content is owing to coating provided a compact surface, which probably sealed the fruit and provide a protective barrier against oxygen supply for enzymatic oxidation of phenolics (Aminifard et al.,2013). Similar the results obtainedby Dong and Wang et al., (2017) who reported that garlic essential oil into the carboxy methyl cellulose coatings brought a positive effect in maintaining higher concentrations of total phenols and anthocyanins.

Antioxidant activity was expressed in terms of per cent inhibition of DPPH. Here, control berries showed significant decrease in per cent inhibition of DPPH. These results are supported by the findings given by Genova et al., (2011) who found that as storage period increases, antioxidant activity in grapes decreases. Increasing trend in in the percent inhibition was found in all treated berries whereas it decreases with in non-treated berries with the storage period. Control grapes (T4) showed the decline in per cent inhibition from by $4.47 \%$ whereas, $\mathrm{T} 2$ showed increase by $1.01 \%$ followed by T3i.e. $1.08 \%$.

The similar results have been found by Baraiya et al., (2016) who coated grapes by xanthan gum incorporated with different 
antioxidants. Their study revealed that incorporation of antioxidants in coating enhanced the level of phenolics, ascorbic acid and total antioxidant activity in grapes. Garlic oil preserved the overall quality and antioxidant capacity of fresh-cut tomatoes (Ayala-Zavala et al., 2008).

The data presented in table 5 reflect that by increasing storage duration PLW were increased in all treatments. Significant differences among treatments were observed in data collected at weekly interval. Control lost shelf life on $7^{\text {th }}$ day of storage (PLW $5.74 \%$ ) while applications of coating (T1 to T3) were recorded $>5 \%$ PLW and minimum PLW (3.42\%) was in T2 closely followed by T3. PLW on other intervals, were maximum in control (T4) which was followed by $\mathrm{T} 1$ where minimum dose of garlic oil $(0.125 \mathrm{ml})$ was added in guar gum. Increased level of garlic oil resulted in decreasing trend in PLW.

Overall minimum PLW was recorded in T2 over the sample collection intervals. The lower rate of PLW in GG-GO-coated grapes relative to control was attributed to the slower rate of respiration induced by a decrease in the water vapour pressure difference between the fruit layer and the ambient atmosphere (Koca et al., 1993).

These results are consistent with the observations of Rehman et al., (2015), who noticed that garlic oil-coated mandarins recorded lower weight loss compared to noncoated mandarins. They added that the reduced weight loss in the case of coated mandarins could be due to the fact that the coating was a deterrent for moisture evaporation. The results of this study corroborated findings of Alam and Paul, (2001) and Thakur et al.,(2002) who also found less water loss due to coating when researching on storage stability for various fruits.
Grape surface is an unstable habitat that changes greatly according to the stage of grape ripening. Different bacteria and yeasts can colonize the surface of grape berry and the diversity of microorganisms depends on the stage of ripening, pesticide application and health condition. In the present study, in case of bacterial count no growth was observed upto $7^{\text {th }}$ day of storage. After 7 days, significant growth was observed onto the surface of berries. Here, on the $14^{\text {th }}$ day of storage $19 \times 10^{2} \mathrm{CFU} / \mathrm{ml}$ was found. Contrary to this, no bacterial growth was observed on berries treated with $\mathrm{T} 2$ on $14^{\text {th }}$ day of storage. On the $28^{\text {th }}$ day of storage, T4 (non-treated) showed the highest bacterial growth i.e. $82 \mathrm{X}$ $10^{2} \mathrm{CFU} / \mathrm{ml}$ followed by $\mathrm{T} 1$ which was $61 \mathrm{X}$ $10^{2} \mathrm{CFU} / \mathrm{ml}$ whereas, minimum growth of 14 $\mathrm{X} 10^{2} \mathrm{CFU} / \mathrm{ml}$ was observed with treatment T2. On $28^{\text {th }}$ day both treated and non-treated berries has uncountable bacteria on the surface. In case of yeast and mould, upto $14^{\text {th }}$ day of storage treated berries did not show any growth but in case of untreated berries, 4 X $10^{3} \mathrm{CFU} / \mathrm{ml}$ count was found. Maximum yeast and mould count was found on $28^{\text {th }}$ day of storage which is $10 \mathrm{X} 10^{3} \mathrm{CFU} / \mathrm{ml}$ while minimum count was $4 \times 10^{3} \mathrm{CFU} / \mathrm{ml}$ in $\mathrm{T} 2$. From the results it can be concluded that garlic oil in combination with guar gum retard the microbial growth onto the surface of grape berries. These findings are in agreement with of Asik and Candogan (2014) who reported the effectiveness of chitosan coatings incorporating garlic oil in reducing aerobic bacteria counts and extending the refrigerated shelf life of shrimp meat. Spraying of tomato fruits with $10 \%$ garlic retarded the spoilage and enhanced the shelf-life of fresh-cut tomatoes (Ayala-Zavala et al., 2008).They also reported that microbial growth of freshcut tomato treated with garlic oil at different concentrations (50, 100 and $200 \mu \mathrm{g}$ of essential oil/100 $\mathrm{g}$ of tomato) showed a major inhibition at the highest treatment concentration; however, the lower 
concentration treatment that showed no significant effect on inhibition of microbial growth, was the only treatment acceptable for consumers.

The present investigation concluded that grape berries treated garlic oil enhanced the physico-chemical properties. On the other hand non-treated berries showed maximum weight loss and also greater difference in total soluble solids, titratable acidity, total phenol content, antioxidant activity. Non-treated berries showed significant growth of microbes on their surface. Among all treatment, $0.5 \%$ GO delayed the changes in total soluble solids, titratable acidity. Also, total phenol content and antioxidant activity was increased by the addition of garlic oil at the level of $0.5 \%$ followed by garlic oil at the level of $1 \%$. There was non-significant difference in 0.5 and $1 \%$ treated berries in physic-chemical and microbial analysis. By considering the strong aroma of garlic oil, $0.5 \%$ garlic oil was selected as best treatment.

\section{Acknowledgment}

The authors thank the MIT College of Food Technology, MIT ADT University, Pune and ICAR- National Research Centre for Grapes, Pune for all the support and encouragement.

\section{References}

Alam, M.D.S. and Paul, S. 2001. Efficacy of Casein coating on storage behavior of Kinnow. Journal of Food Science and Technology. 38(3): 235-238.

Aminifard, M., Aroiee, H., Azizi, M., Nemati, H andJaafar, H. 2013. Effect of compost on antioxidant components and fruit quality of sweet pepper (capsicum annuum L.). Journal of Central European Agriculture. 14: 47-56.

Altunkaya, A., \&Gokmen, V. 2008. Effect of Various Inhibitors on Enzymatic Browning, Antioxidant Activity and Total
Phenol Content of Fresh Lettuce (Lactuca sativa).Food Chemistry. 107(3): 11731179.

Asghari, M.2014. Effect of salicylic acid and edible coating based aloe vera gel treatment on storage life and postharvest quality of grape. Intl J Agri Crop Sci. 5 (23):2890-2898.

Asik, E., and Candogan, K. 2014. Effects of Chitosan Coatings Incorporated with Garlic Oil on Quality Characteristics of Shrimp. Journal of Food Quality. 37(4): 237-246

Ayala-Zavala, J.F., Oms-Oliu, G., OdriozolaSerrano, I., Gonzalez-Aguilar, G.A., Alvarez-Parrilla, E. and Martin-Belloso, O. 2008. Biopreservation of fresh-cut tomatoes using natural antimicrobials. European Food Research and Technology, 226: 1047-1055.

Baraiya, N., Ramana, R. T. V. and Thakkar, V. 2016. Composite coating as a carrier of antioxidants improves the postharvest shelf life and quality of table grapes (Vitisvinifera 1. var. Thompson seedless). Journal of Agricultural Science and Technology. 18. 93-107.

Corzo-Martinez, M., Corzo, N., and Villamiel, M. 2007. Biological Properties of Onions and Garlic.Trends in Food Science and Technology.18(12):609-625.

Crisosto, C. H., Garner, D., and Crisosto, G. 2002. Carbon Dioxide-enriched Atmospheres during Cold Storage Limit Losses from Botrytis but Accelerate Rachis Browning of 'Redglobe' Table Grapes.Postharvest Biology and Technology. 26(2): 181-189.

Dong, F., and Wang, X. 2017. Effects of Carboxymethyl Cellulose Incorporated with Garlic Essential Oil Composite Coatings for Improving Quality of Strawberries. International Journal of Biological Macromolecules. 104- Part A, 821-826.

FAO, Food and Agriculture Organization.1992. Manual of Food Quality Control. 4, Rev. I Microbiological analysis Washington, D.C. 
Gol, N. B., Patel, P. R., \&Rao, T. V. R. 2013. Improvement of quality and shelflife of strawberries with edible coatings enriched with chitosan. Postharvest Biology and Technology. 85: 185-195.

Guilbert, S., Gontard, N., \&Gorris, L. G. M. 1996. Prolongation of the Shelf-life of Perishable Food Products Using Biodegradable Films and Coatings. LWT Food Science and Technology. 29(1-2): 10-17.

Koca, R.W., Hellickson, M. L. and Chen, P. M. 1993. Mass Transfer From 'd Anjou' Pears in CA Storage. Transactions of the ASAE. 36(3): 821-826.

Martínez, K., Ortiz, M., Albis, A., Gilma Gutiérrez Castañeda, C., Valencia, M., and Grande Tovar, C. 2018. The Effect of Edible Chitosan Coatings Incorporated with Thymus capitatus Essential Oil on the Shelf-Life of Strawberry (Fragaria $x$ ananassa) during Cold Storage. Biomolecules. 8(4): 155.

Naik, D.M., V.G. Mulekar, C.G. Chandel, and B.M. Kapse. 1993. Effect of prepackaging on physico-chemical changes in tomato (Lycopersiconesculentum Mill.) during storage. Indian Food Packer. 9-13.

Ponce, A. G., Roura, S. I., Valle, C. E. D., \& Moreira, M. R. 2008. Antimicrobial and Antioxidant Activities of Edible Coatings Enriched with Natural Plant Extracts: In Vitro and in Vivo Studies.Postharvest Biology and Technology. 49(2): 294-300.

Pranoto, Y., Salokhe, V. M., and Rakshit, S. K. 2005. Physical and Antibacterial Properties of Alginate-based Edible Film Incorporated with Garlic Oil. Food Research International. 38(3):267-272.

Rehman, H., Farooq, U., Akram, K., Sidhu, A.,
Shafi, A., \&Sarfraz, F. 2015. Incorporation of garlic extract as antifungal agent in psyllium based edible coating for mandarin. International Journal Of Food And Allied Sciences. 1(1): 11-17.

Restrepo, D.A., Molina, F.A., Cabrera, K.R.2010. Effect of the Addition of Kappa I.II Carrageenan and Tara Gum on Quality Characteristics of Cooked and Chopped Pork Hams. Rev.Fac.Nal.Agr.Medellín 63(2): 5717-5727.

Sharma, A. K., Somkuwar, R. G., Upadhyay, A. K., Sawant, S. D. and Naik, S. 2018. Production of quality and safe dried grapes. pp. 12.

Singleton, V.L. and Rossi, J.A. 1965. Colorimetry of total phenolics with phosphomolybdic-phosphotungstic acid reagents. Am. J. Enol. Vitic. 16:144- 158.

Thakur, K.S., Kaushal, B.B. and Sharma, R.M.. 2002. Effect of different post-harvest treatments and storage conditions on the fruit quality of Kinnow. Journal of Food Science and Technology. 39: 609-618.

Tharanathan, R. N. 2003. Biodegradable films and composite coatings: past, present and future. Trends Food Sci Technol., 14: 7178

Ullah, A., Abbasi, N. A., Shafique, M., \& Qureshi, A. A. 2017. Influence of Edible Coatings on Biochemical Fruit Quality and Storage Life of Bell Pepper cv. "Yolo Wonder." Journal of Food Quality, 1-11

Viuda-Martos, M., Mohamady, M. A., Fernández-López, J., AbdElRazik, K. A., Omer, E. A., Pérez-Alvarez, J. A., \&Sendra, E. 2011. In vitro antioxidant and antibacterial activities of essentials oils obtained from Egyptian aromatic plants. Food Control.

\section{How to cite this article:}

Jagruti Jankar, Vasant Pawar, Ajay KumarSharma. 2020. Study of Application of Composite Coating of Guar Gum-Garlic Oil on Grapes. Int.J.Curr.Microbiol.App.Sci. 9(01): 2378-2386. doi: https://doi.org/10.20546/ijcmas.2020.901.271 